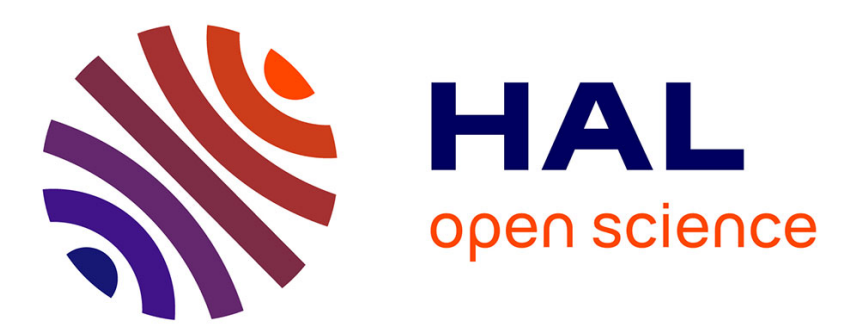

\title{
Preliminary study on the mechanical behaviour of heat exchanger pile in physical model
}

Argyro Kalantidou, Anh Minh A.M. Tang, Jean-Michel Pereira, Ghazi Hassen

\section{To cite this version:}

Argyro Kalantidou, Anh Minh A.M. Tang, Jean-Michel Pereira, Ghazi Hassen. Preliminary study on the mechanical behaviour of heat exchanger pile in physical model. Geotechnique, 2012, 62 (11), pp.1047-1051. 10.1680/geot.11.T.013 . hal-00772584

\section{HAL Id: hal-00772584 \\ https://hal-enpc.archives-ouvertes.fr/hal-00772584}

Submitted on 10 Jan 2013

HAL is a multi-disciplinary open access archive for the deposit and dissemination of scientific research documents, whether they are published or not. The documents may come from teaching and research institutions in France or abroad, or from public or private research centers.
L'archive ouverte pluridisciplinaire HAL, est destinée au dépôt et à la diffusion de documents scientifiques de niveau recherche, publiés ou non, émanant des établissements d'enseignement et de recherche français ou étrangers, des laboratoires publics ou privés. 


\title{
Preliminary study on the mechanical behaviour of heat exchanger pile in physical model
}

\author{
Argyro KALANTIDOU, BEng, MSc; Anh Minh TANG, BEng, PhD; Jean-Michel PEREIRA, BEng, \\ PhD; Ghazi HASSEN, BEng, PhD.
}

Université Paris-Est, Laboratoire Navier

Corresponding author

Dr. Anh Minh TANG

Université Paris-Est

Laboratoire Navier

Ecole des Ponts ParisTech

6-8 avenue Blaise Pascal, Cité Descartes, Champs-sur-Marne

77455 Marne-la-Vallée

France

Email : anhminh.tang@enpc.fr

Phone : +33164153563

Fax : +33164153562

Number of words in main text: 1980 


\title{
Number of Figures: 6
}

\begin{abstract}
:
The effects of temperature changes on the mechanical behaviour of heat exchanger piles are necessary to be taken into account in geotechnical design. In this preliminary study, the behaviour of an axially loaded pile under thermal cycles was investigated using a physical model. After applying the axial load by dead weights on the pile's head, the pile was heated from $25{ }^{\circ} \mathrm{C}$ to $50{ }^{\circ} \mathrm{C}$ and subsequently cooled to $25^{\circ} \mathrm{C}$. Four tests (corresponding to four values of axial load) were performed and two temperature cycles were undertaken in each test. The pile's temperature and the pile head displacement were monitored. When low axial loads were applied, the heating induced heave and cooling induced settlement of the pile's head. In this case, the displacement-temperature curve was found to be reversible and similar to the thermal expansion curve of the pile. However, in the case of higher axial loads, the heave of the pile's head, obtained during heating, was lower than the thermal expansion of the pile demonstrating the settlement of the pile's toe. Reversible settlement of the pile's head was also observed after these thermal cycles.
\end{abstract}

2

Key words: Model tests, heat exchanger pile, settlement, soil/structure interaction, temperature effects. 


\section{INTRODUCTION}

A heat exchanger or geothermal pile is one of the sustainable technologies for intermittent energy storage in soil. It consists of a foundation pile equipped with a tube or a pipe network through which a fluid flows in order to exchange heat with the surrounding soil. Although this technology has widely been used recently in Austria, Germany, Switzerland, and the United Kingdom (Moel et al., 2010), it is still rarely used in France, mainly due to the absence of reliable technical assessment and guarantees. Actually, the design of geothermal piles is derived primarily from the building energy demands and the thermal properties of its main components. According to Peron et al. (2011), there is currently a lack of established calculation method for the geotechnical design of geothermal piles and dimensioning has been based on empirical considerations. Improved knowledge on geotechnical design methods and the mechanisms induced by heat transfer is at the forefront of research today in geotechnical engineering. Recent studies include in situ tests (Laloui et al., 2003; Bourne Webb et al., 2009), numerical simulations (Peron et al., 2011; Silvani et al., 2009; Laloui et al., 2006; Brandl, 2006) and laboratory tests in centrifuge (McCartney and Rosenberg, 2011). In these studies, the main effect induced by temperature increase was observed to be the appearance of additional stresses inside the pile, which can be twice higher than those observed from the application of mechanical loading. In fact, the thermal expansion of the pile during heating can increase the soil/pile friction mobilisation and create further compressive stresses in the pile. Nevertheless, the in situ tests conducted have shown that the strains induced during heating/cooling are reversible and their impact on the performance is negligible.

The present study aims at investigating the effects of a pile head loading on the pile/soil behaviour under thermal cycles using $1 \mathrm{~g}$ model tests in sand.

\section{EXPERIMENTAL METHOD}


The experimental setup is presented in Fig. 1. The model pile is a closed end aluminium tube of 800 mm length, with external and internal diameters of $20 \mathrm{~mm}$ and $18 \mathrm{~mm}$ respectively. After fixing the pile in the centre of a 570-mm inner diameter cylindrical steel tank with the aid of a temporary support, dry Fontainebleau sand (with a mean grain size value $0.23 \mathrm{~mm}$ ) was compacted around the pile by using a wood tamper. The target dry density was set to $1.51 \mathrm{Mg} / \mathrm{m}^{3}$ (corresponding to a relative density of $46 \%$ ), equal to that chosen in the work of De Gennaro et al. (1999). This method of pile installation represents more closely the installation of non-displacement piles, mainly used in the technology of geothermal foundations and in experimental tests aiming at simulating the behaviour of bored piles (Fioravante, 2002). For the control of the pile's temperature, a metallic Utube of 3-mm external diameter and 2-mm internal diameter was inserted inside the pile in its total length. The U-tube is connected with a temperature-controlled bath and a peristaltic pump. This system allows the circulation of temperature-controlled water inside the U-tube and is thus able to both heat and cool the pile to the target temperature. The uniform heating and cooling of the pile was achieved by filling the pile's interior with water, while the temperature was measured by placing a temperature sensor at the middle of the pile. Actually, the temperature distribution in the model pile could be different to that of a concrete pile. The thermal currents inside the pile were not considered and the pile's temperature is assumed homogeneous and equal to the temperature measured by the temperature sensor.

The load was vertically applied by dead weights at the top of the pile using a loading guide system. For the measurement of the pile's vertical displacement, a displacement transducer was fixed at its head via a small steel plate.

Four tests were performed, each of them included the following steps: (1) soil compaction and installation of the experimental setup; (2) loading of the pile's head in increments; (3) application of heating and cooling cycles. The axial pile head loads in each test are: $0,200,400$, and $500 \mathrm{~N}$ for 
Tests 1, 2, 3 and 4 respectively. The thermal cycles were applied immediately after mechanical loading. The temperature of the pile was first increased from the laboratory temperature (close to 25 $\left.{ }^{\circ} \mathrm{C}\right)$ to $50{ }^{\circ} \mathrm{C}$ and then decreased to $25^{\circ} \mathrm{C}$. Two thermal cycles were applied for each test.

\section{EXPERIMENTAL RESULTS}

The pile head settlement obtained by the application of different pile head loads (Tests $2,3,4)$ is presented in Fig. 2. It can be observed that the displacement is relatively small (less than $0.2 \mathrm{~mm}$ or $1 \%$ of pile diameter) for a load lower than $200 \mathrm{~N}$. An exponential equation was fitted to the results in order to be able to infer the ultimate load. Assuming that the ultimate load of the pile corresponds to the load causing a settlement of $10 \%$ pile diameter, the ultimate bearing capacity of the pile was estimated at $525 \mathrm{~N}$. In Fig. 2, the interval of the pile head displacement obtained during the subsequent thermal phase is also plotted for each test.

The results of Test 1 are shown in Fig. 3. It can be seen that incremental heating induced incremental heaves of the pile head (Fig. 3b). In Fig. 3c, the pile head settlement is plotted versus the pile's temperature for the two cycles. In this figure, the thermal expansion/contraction curve of the aluminium pile is also plotted. This reference curve corresponds to the head displacement of a pile subjected to temperature changes, when its toe is fixed. The experimental results of Test 1 (Fig. $3 c$ ) during the first heating show a settlement/temperature slope similar to that of the pile's thermal expansion curve and subsequently the first cooling path joins the thermal contraction curve progressively. At the same time, a hysteresis phenomenon, i.e. distinct heating and cooling paths, can be observed in both cycles. The results of Test 2 are shown in Fig. 4. It is noticeable that the graph of settlement versus time (Fig. $4 b$ ) is similar to that of temperature versus time. When plotting the pile head settlement versus temperature (Fig. 4c), the main features observed in Test 1 can also be found. The results of Test 3 (Fig. 5) in terms of pile head displacement show a settlement of $0.4 \mathrm{~mm}$ after the first cycle (Fig. 5b). This phenomenon was not observed for the tests having lower pile head load 
(Test 1 and Test 2). In Fig. $5 c$, it can be seen that the pile head heave obtained during the first heating path is significantly lower than the pile thermal expansion curve. Yet, the cooling path follows the same slope as that of the pile thermal contraction curve. The second heating induced heave and resulted in a settlement/temperature change slope relatively higher than that of the first heating path but still lower than that of the pile thermal expansion curve. On the other hand, the pile behaviour during the second cooling path is similar to the first cooling path and the total settlement of the pile head after two thermal cycles is $0.5 \mathrm{~mm}$. In Test 4 (Fig. $6 a, b, c)$ the behaviour of the pile is similar to that corresponding to Test 3 .

\section{DISCUSSION}

In this preliminary study, the pile can be assumed incompressible under mechanical loading in the considered mechanical loading range $(0-500 \mathrm{~N})$. Actually, for a given load of $525 \mathrm{~N}$, the amount of compression is equal $0.076 \mathrm{~mm}$. As a result, the measured pile's head displacement during the loading phase represents the pile's toe displacement. In the case of Test 1 and Test 2, the pile's head (and toe) displacement obtained during the loading phase is small (less than $1 \%$ of the pile's diameter). Heating induced a thermal dilation of the pile and a pile head displacement similar to the reference thermal expansion curve (head displacement of a pile subjected to temperature changes when its toe is fixed). This means that the mobilized pile base capacity remains small, much lower than the ultimate resistance. In fact, the axial dilation of the pile during heating would inverse the direction of the mobilized shaft friction. Taking into account that the soil has a tendency to restrain the heave of the pile's head, additional stress can be developed in the pile's toe (as explained by Laloui et al., 2003; Bourne-Webb et al., 2009). Nevertheless, the additional stress induced by heating did not cause settlement of the pile's toe.

This is not the case for Test 3 and Test 4 where higher loads were applied. As shown in the loadsettlement curve (Fig. 2), the load applied in these tests (400 N in Test 3 and $500 \mathrm{~N}$ in Test 4) is close 
to the ultimate load (estimated at $525 \mathrm{~N}$ following the fitting curve). As a result, additional stress at the pile's toe induced by heating would lead to additional settlement and the development of irreversible strain. That explains why the pile head heave obtained during heating is significantly lower than the pile thermal expansion curve (Fig. 5 and Fig. 6) and why irreversible settlement were observed after the thermal cycles of these tests.

An analysis on the time-dependent behaviour of the pile in Tests 1 and 2 shows a slight difference between the first and second thermal cycle of each test. At the same temperature, the pile's head in the second cycle is situated lower than the first cycle. And it can be expected that the pile continued to settle during these cycles. This creep behaviour can be also used to explain the large increase in displacement for a small temperature change at the end of each cooling phase in Tests 3 and 4 (Fig. 5 and Fig. 6). Actually, the duration of these cooling phases is high (comparing to the duration of heating phases) and the measured pile displacement would included both thermal contraction and creep settlement.

At the beginning of each cooling phase, there is a plateau in the temperature-displacement curve where displacement does not appear to be mobilised although cooling has begun. This would be explained by the temperature heterogeneity along the pile and between its various elements (temperature sensor, U-tube, aluminium tube, etc.). In addition, heat diffusion from the pile to the surrounding soil can be equally considered to explain this phenomenon.

Finally, it should be noted that the significant scattering of the experimental data of the loaddisplacement plots (Fig. 2) is mainly related to load application method. Actually, the application of dead weighs, that was chosen to achieve a constant load on the pile's head during thermal cycles, induces slight shocks on its head. In the future work, the loading system will be improved allowing a progressive increase of weigh. At the same time, strain gauges will be added along the pile in order to monitor the stress distribution. 


\section{CONCLUSION}

In this preliminary study, the behaviour of piles subjected to thermal cycles under different constant axial loads was investigated using a physical model. The results would be useful to improve the knowledge on the mechanical behaviour of heat exchanger piles in geothermal foundations. Four tests were performed in compacted Fontainebleau sand with different axial pile head loads. The pile response appears to be "thermo-elastic" under thermal cycles when the mechanical load is less than about $40 \%$ of the ultimate resistance, i.e. the global factor-of-safety is greater than 2.5 . So, at least for this case, conventional factors-of-safety appear adequate to ensure stable pile response under thermal load. Of course, the effect of many cycles of loading needs to be investigated to confirm this finding. When the mechanical load exceeds $40 \%$ of the ultimate resistance, irreversible pile settlement appears to develop. However, at loads close to the pile ultimate resistance, any temperature effects are combined with creep and further work is needed in order to decouple these effects.

\section{ACKNOWLEDGEMENT}

The authors would like to express their great appreciation to the French National Research Agency for funding the present study, which is part of the project PiNRJ "Geotechnical aspects of foundation energy piles" - ANR 2010 JCJC 090801.

\section{REFERENCES}

Bourne-Webb, P., Amatya, B., Soga, K., Amis, T., Davidson, C. \& Payne, P. (2009). Energy pile test at Lambeth College, London: geotechnical and thermodynamic aspects of pile response to heat cycles. Géotechnique 59, No. 3, 237-248. 
Brandl, H. (2006). Energy foundations and other thermo-active ground structures. Géotechnique 56, No. 2, 81-122.

De Gennaro, V., Frank, R., Pande, G.N. \& Canou, J. (1999). Finite element modelling of model piles in calibration chamber. Proceedings of the $7^{\text {th }}$ International Symposium on Numerical Models in Geomechanics (Pande, G.N., Pietruszczak, S. and Schweiger, H.F. (eds)). Balkema, Rotterdam, pp. 419-424.

Fioravante, V. (2002). On the shaft friction modelling of non displacement piles in sand. Soils and Foundation 42, No. 2, 23-33.

Laloui, L., Moreni, M. \& Vuilliet, L. (2003). Comportement d'un pieu bi-fonction, fondation et échangeur de chaleur. Canadian Geotechnical Journal 40, No. 2, 388 - 402.

Laloui, L., Nuth, M. \& Vulliet, L. (2006). Experimental and numerical investigation of the behaviour of a heat exchanger pile. International Journal for Numerical and Analytical Methods in Geomechanics 30, No. 8, 763 - 781 .

McCartney, J.S. \& Rosenberg, J. (2011). Impact of Heat Exchange on Side Shear in Thermo-Active Foundations. Proceedings of the Geo-Frontiers 2011 Conference (Jie Han, Daniel E. and Alzamora P.E. (eds)), ASTM, Geotechnical Special Publications (GSP) 211, pp. 488 - 498.

Moel, M.D., Bach, P. M., Bouazza, A., Singh, R.M. \& Sun, J.L.O. (2010). Technological advances and applications of geothermal energy pile foundations and their feasibility in Australia. Renewable and Sustainable Energy Reviews 14, No. 9, 2683-2696.

Peron, H., Knellwolf, C. \& Laloui, L. (2011). A method for the geotechnical design of heat exchanger piles. Proceedings of the Geo-Frontiers 2011 Conference (Jie Han, Daniel E. and Alzamora P.E. (eds)), ASTM, Geotechnical Special Publications (GSP) 211, pp. 470-479. 
Silvani, C., Nuth, M., Laloui, L. \& Peron, H. (2009). Understanding the thermomechanical response of heat exchanger piles. Proceedings of the First International Symposium on Computational

Geomechanics (Pietruszczak S., Pande G., Tamagnini C. and Wan R. (eds.)), pp. 589-596. 


\section{List of captions}

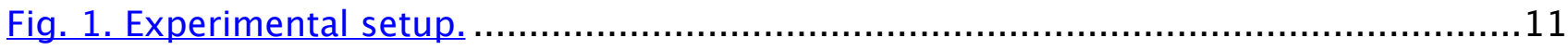

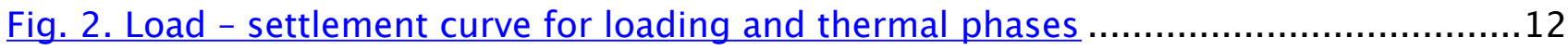

Fig. 3. Experimental results of Test 1. Temperature and pile head settlement during

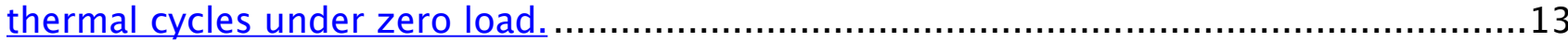

Fig. 4. Experimental results of Test 2. Temperature and pile head settlement during

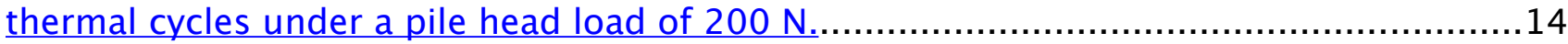

Fig. 5. Experimental results of Test 3. Temperature and pile head settlement during

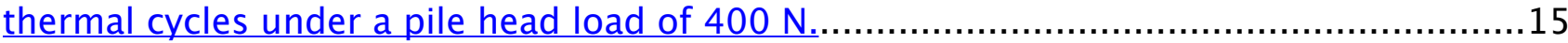

Fig. 6. Experimental results of Test 4. Temperature and pile head settlement during

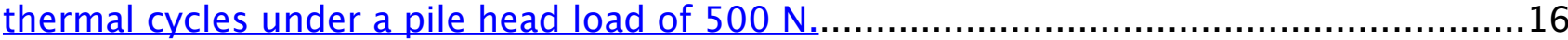




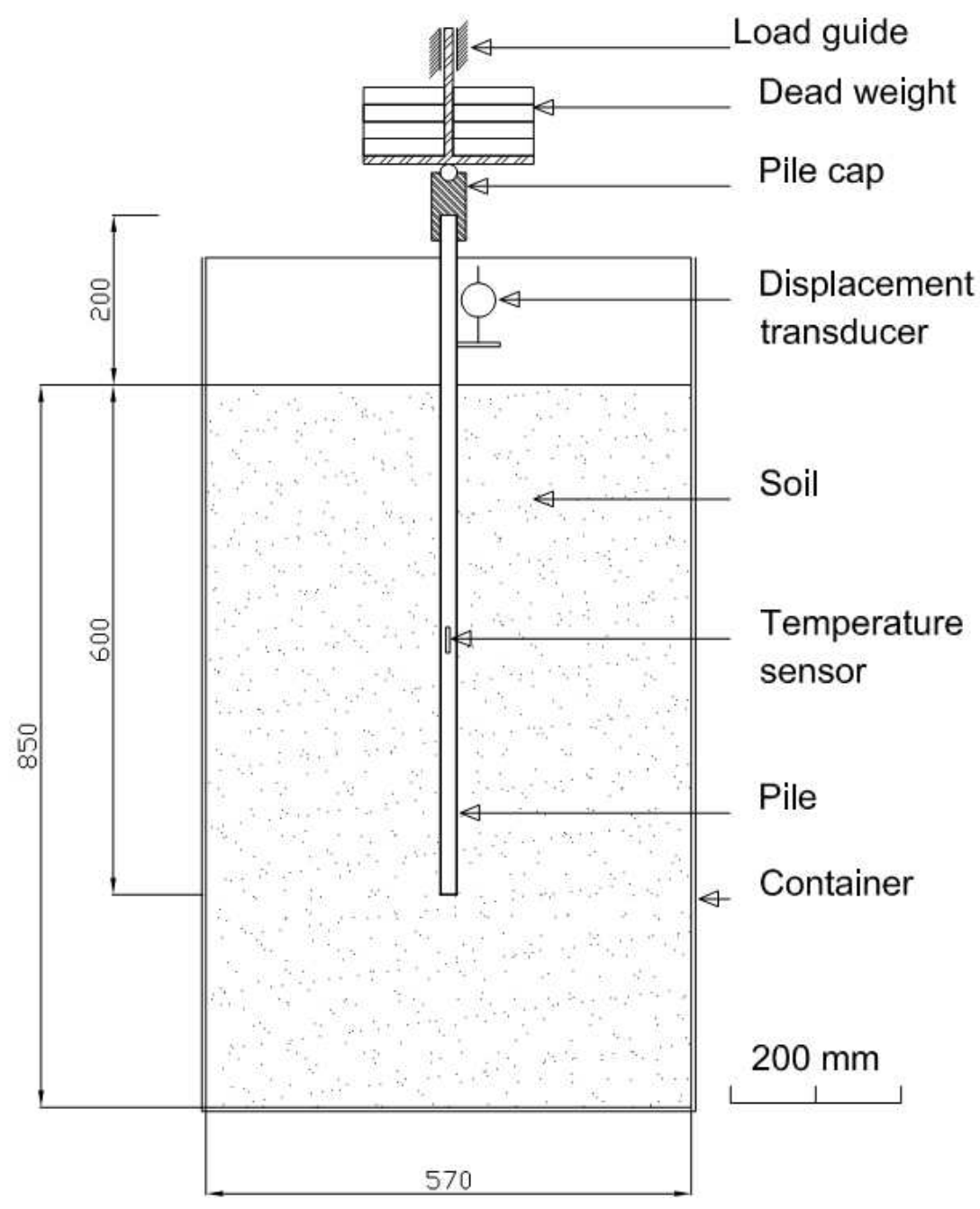

Fig. 1. Experimental setup 


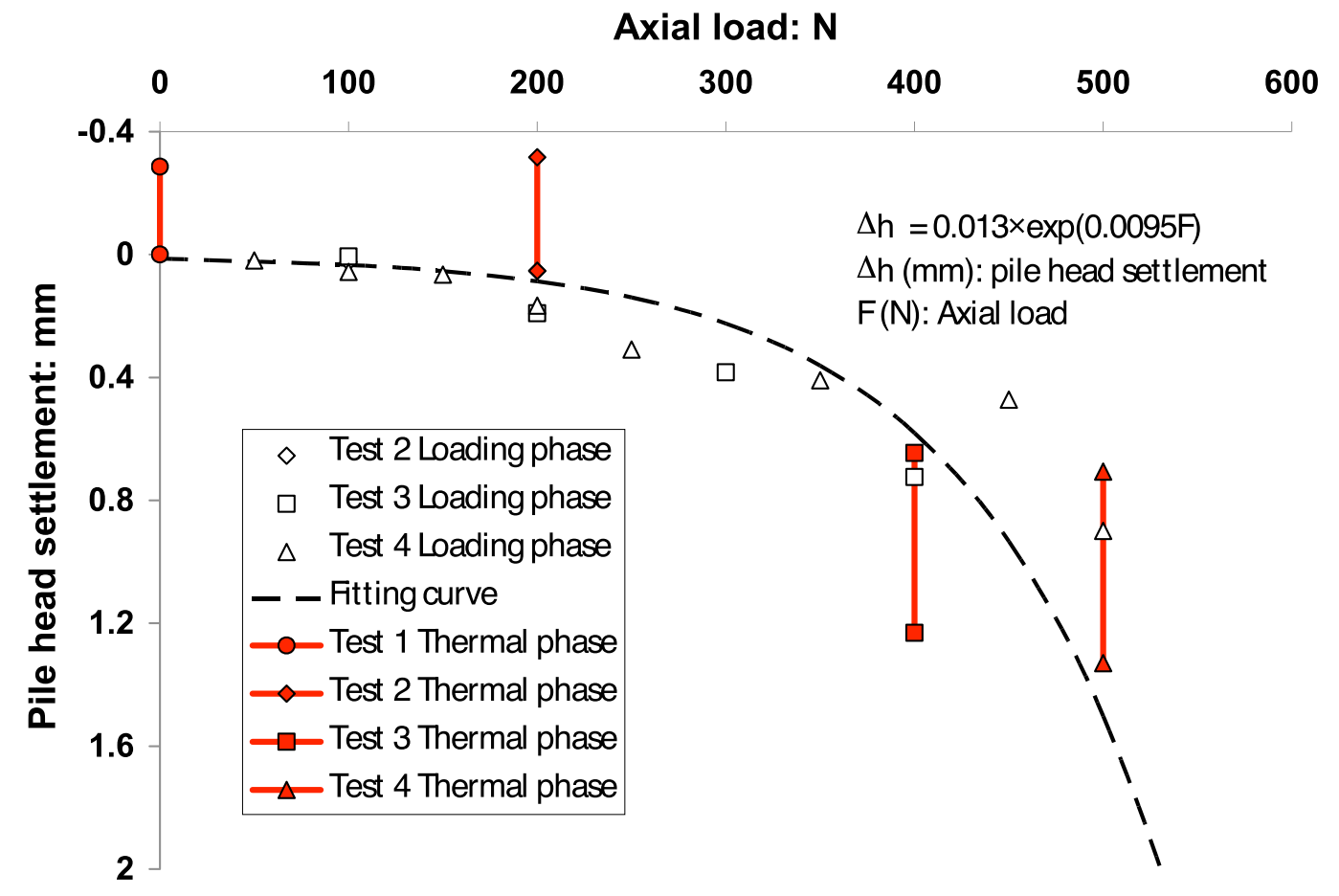

Fig. 2. Load - settlement curve for loading and thermal phases 


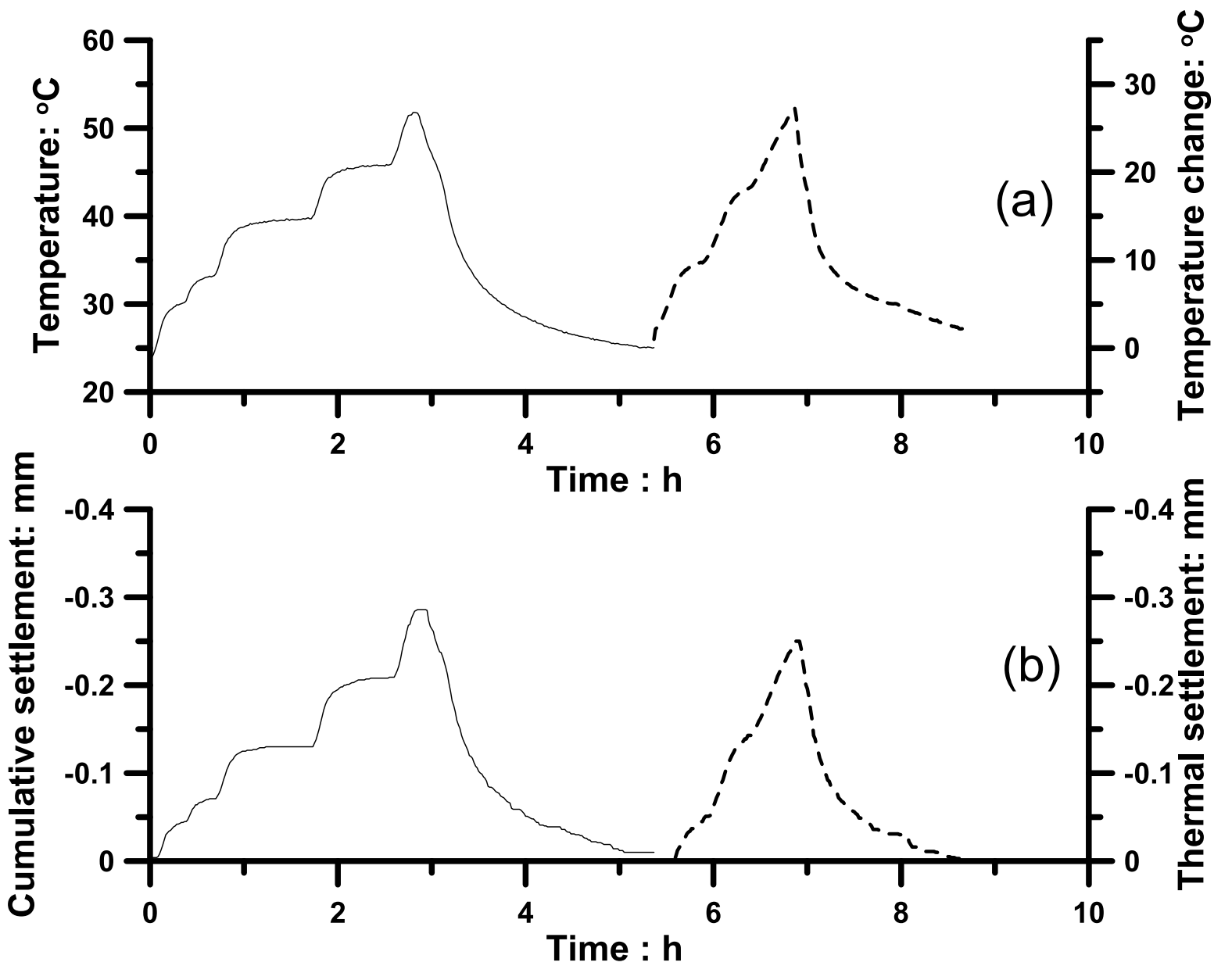

Temperature change: ${ }^{\circ} \mathrm{C}$

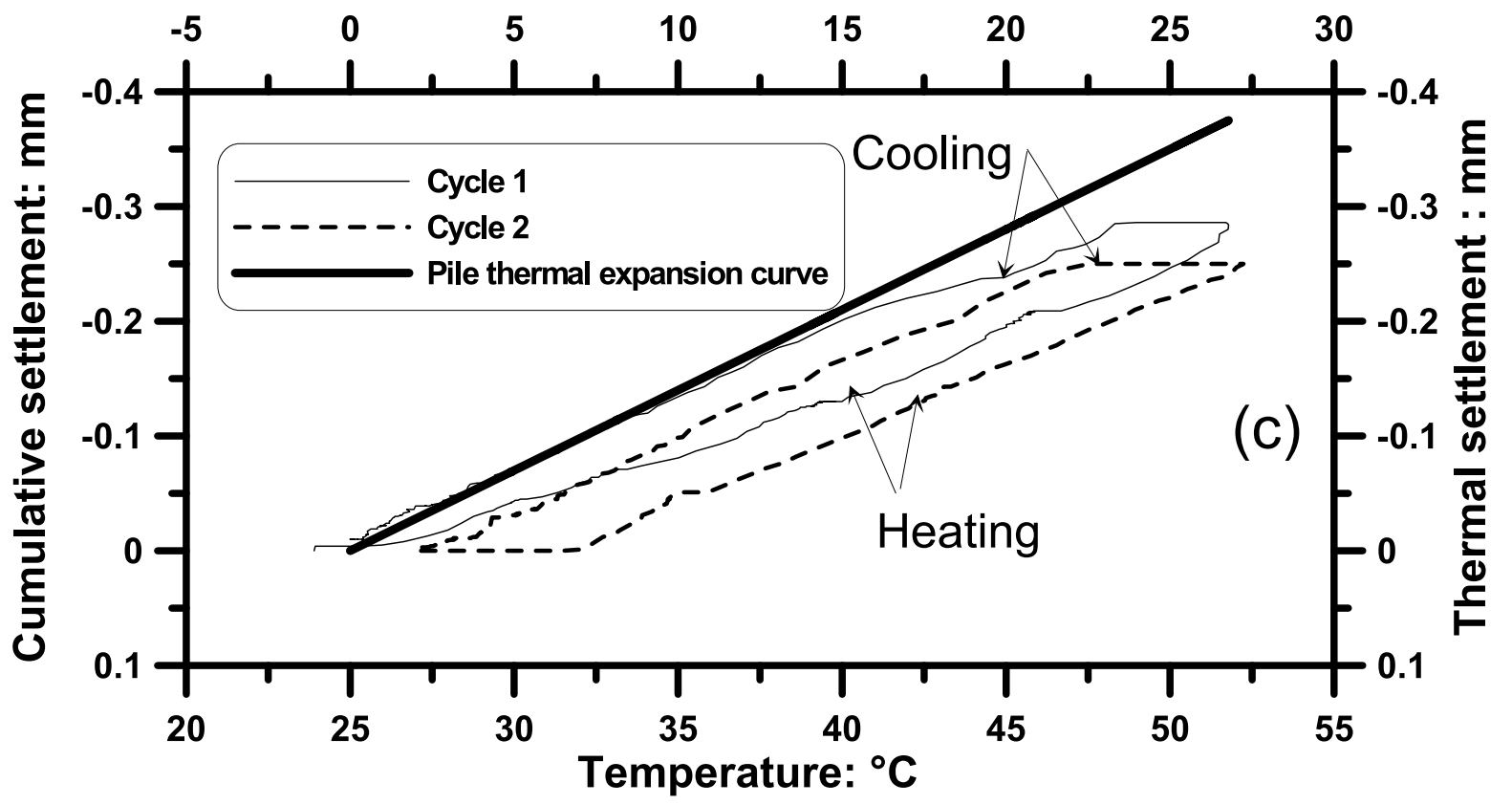

Fig. 3. Experimental results of Test 1 . Temperature and pile head settlement during thermal cycles under zero load. 

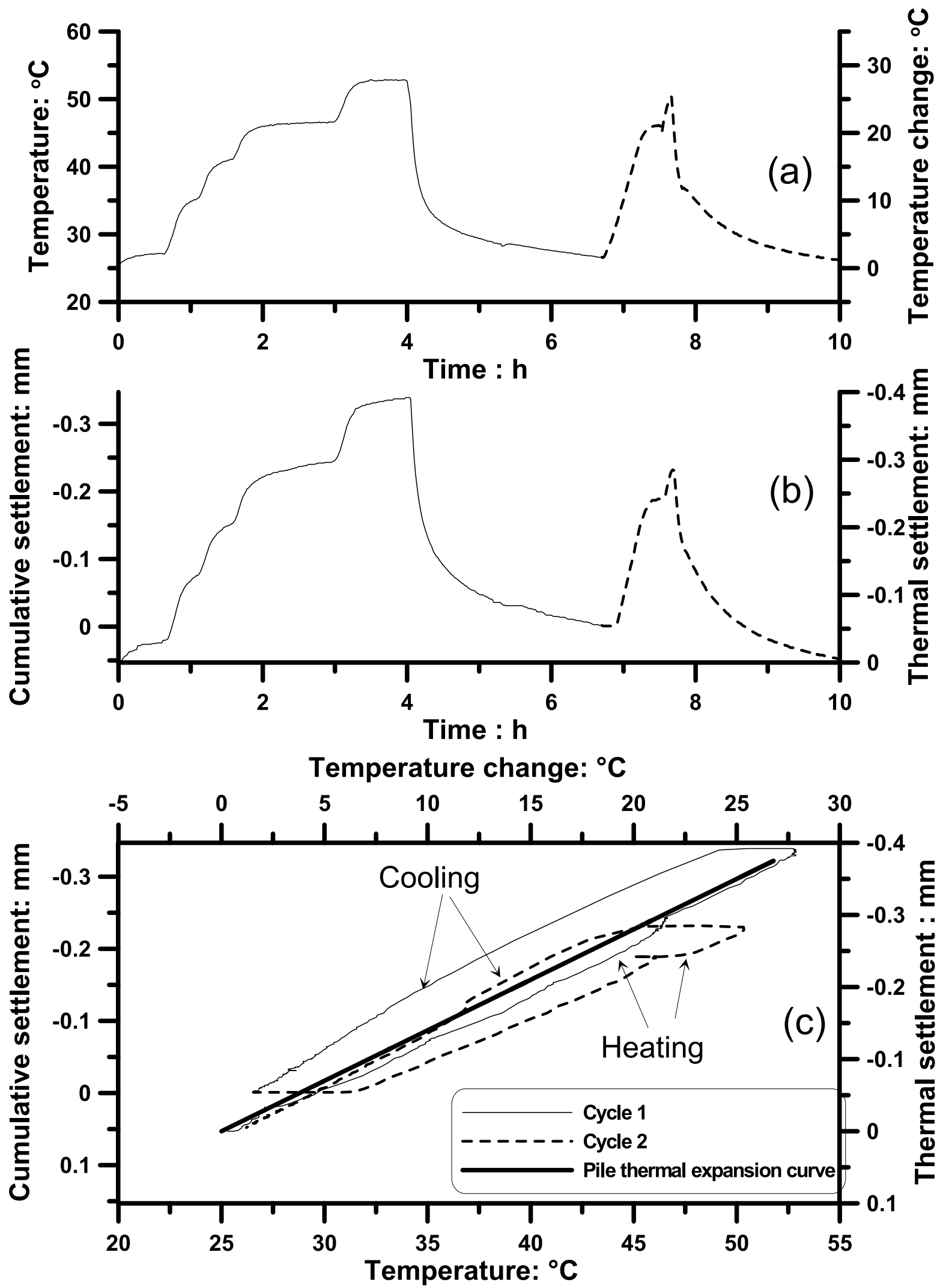

Fig. 4. Experimental results of Test 2. Temperature and pile head settlement during thermal cycles under a pile head load of $200 \mathrm{~N}$. 


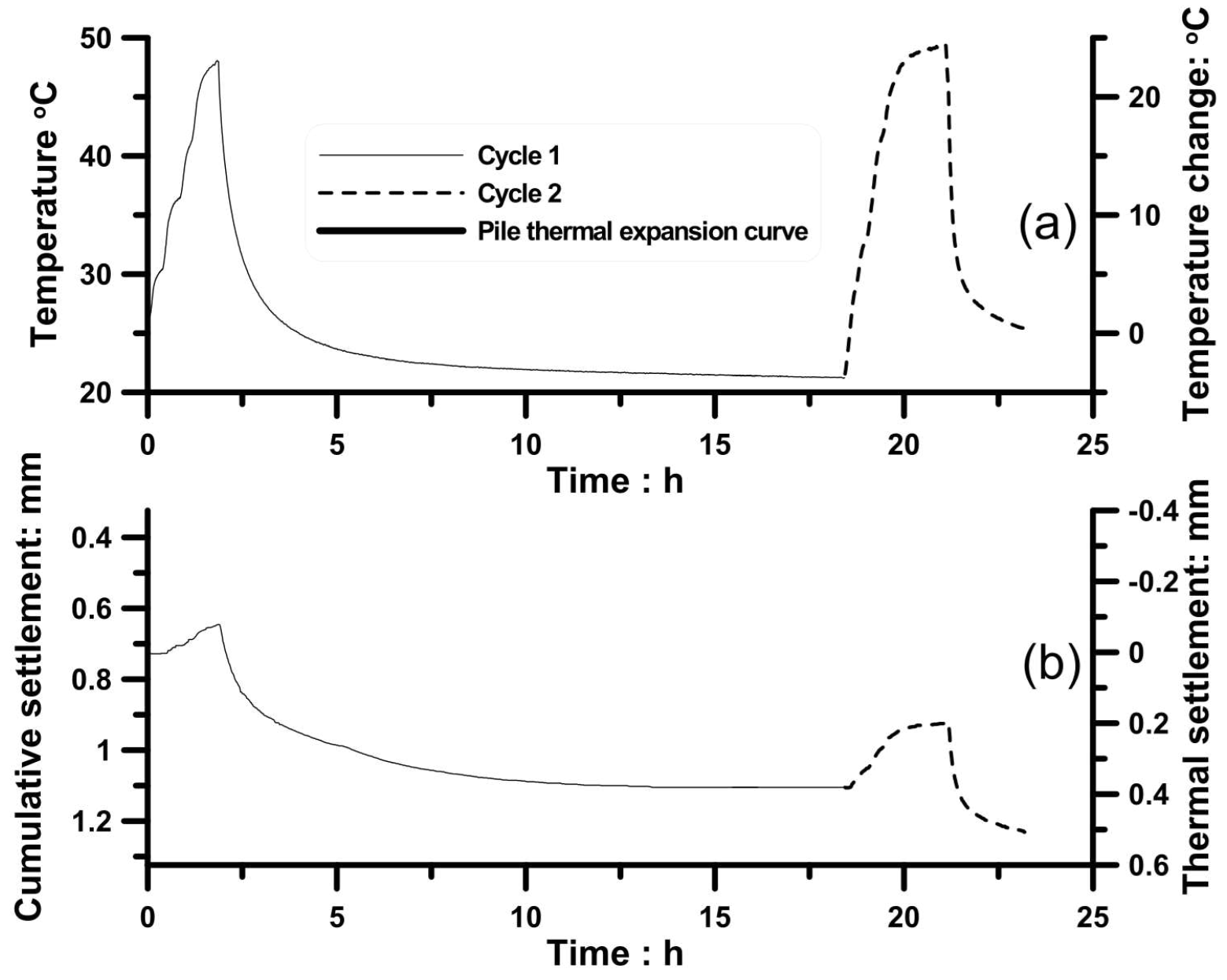

Temperature change: ${ }^{\circ} \mathrm{C}$

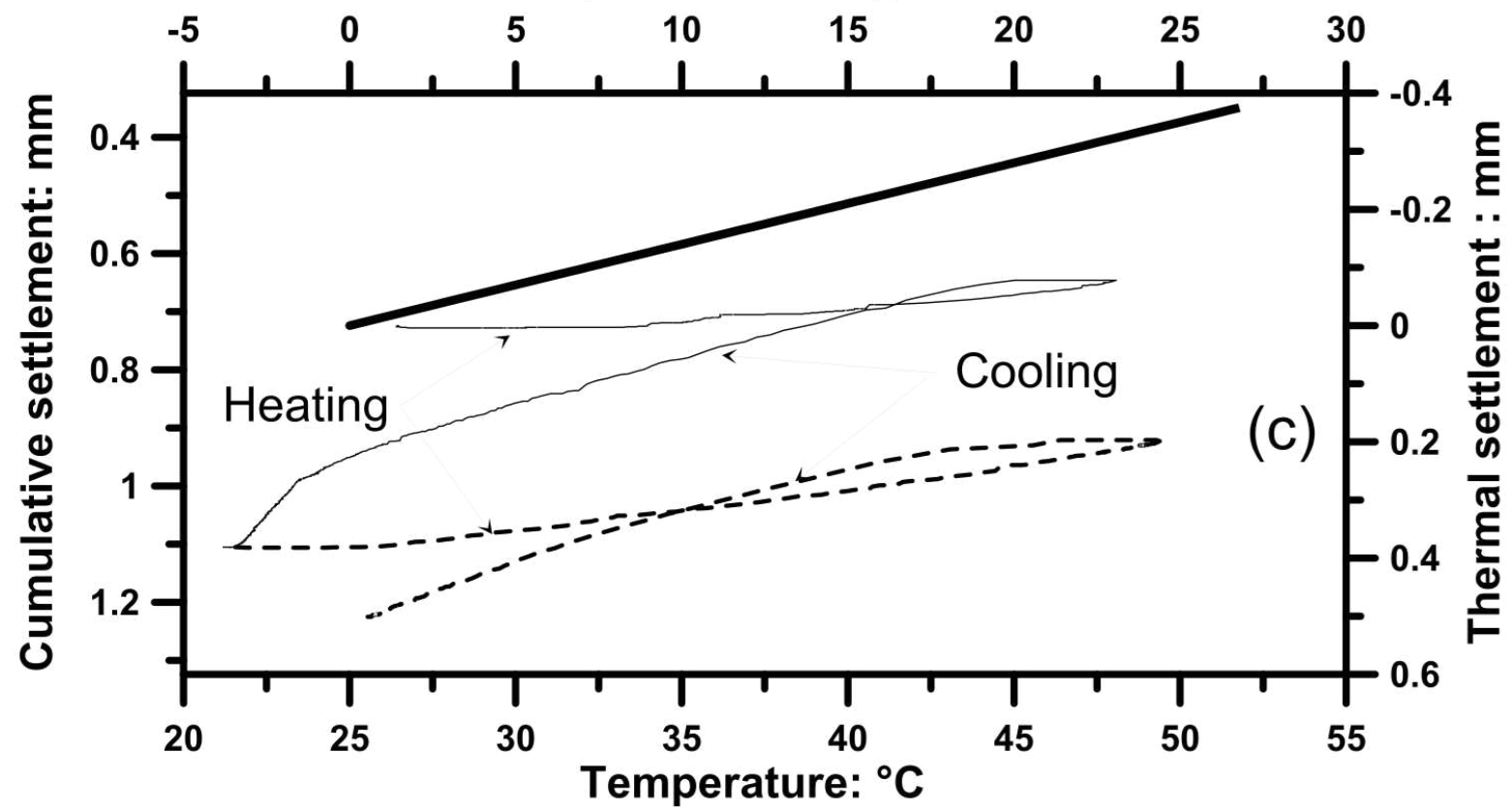

Fig. 5. Experimental results of Test 3. Temperature and pile head settlement during thermal cycles under a pile head load of $400 \mathrm{~N}$. 

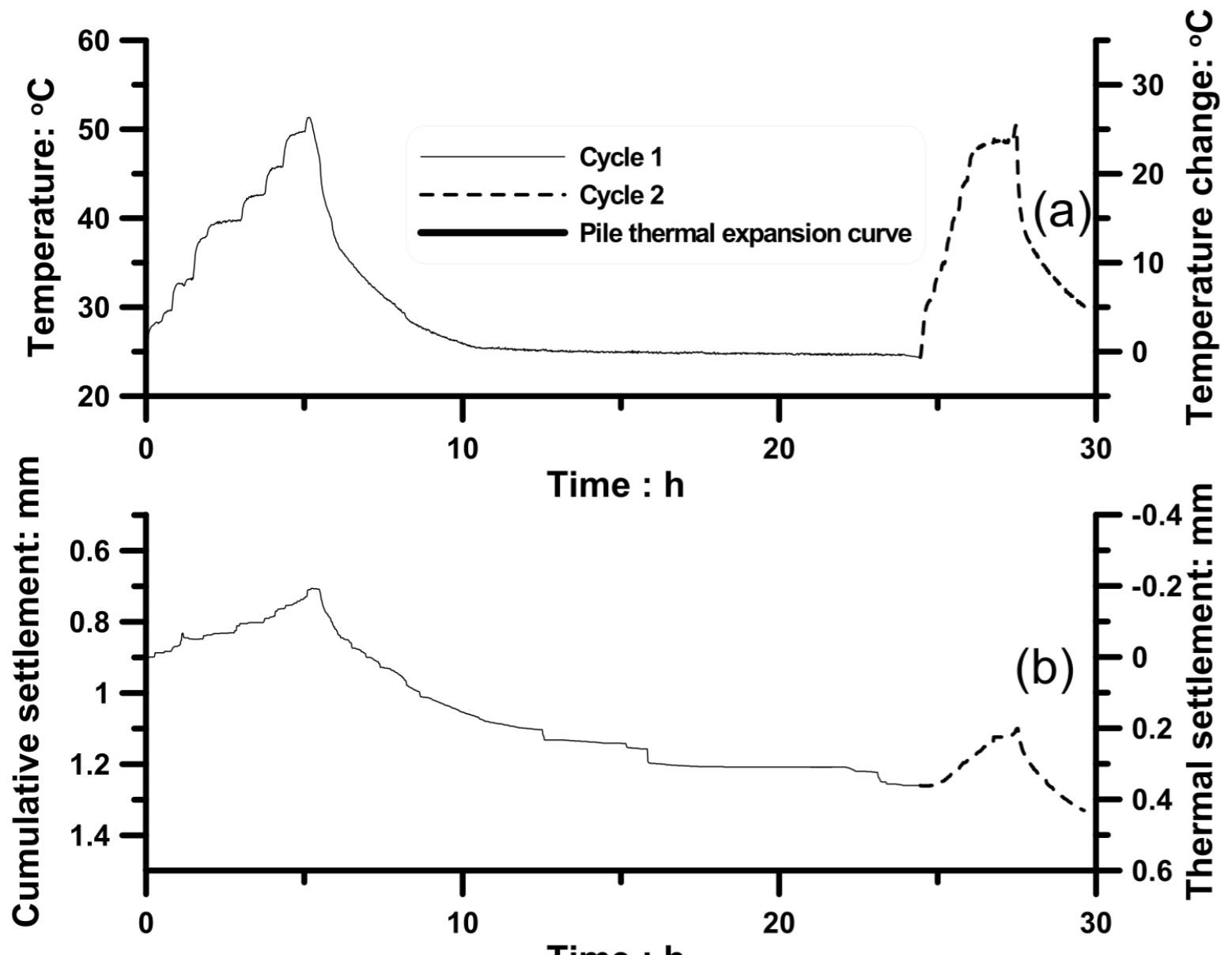

Time : $\mathbf{h}$

Temperature change: ${ }^{\circ} \mathrm{C}$

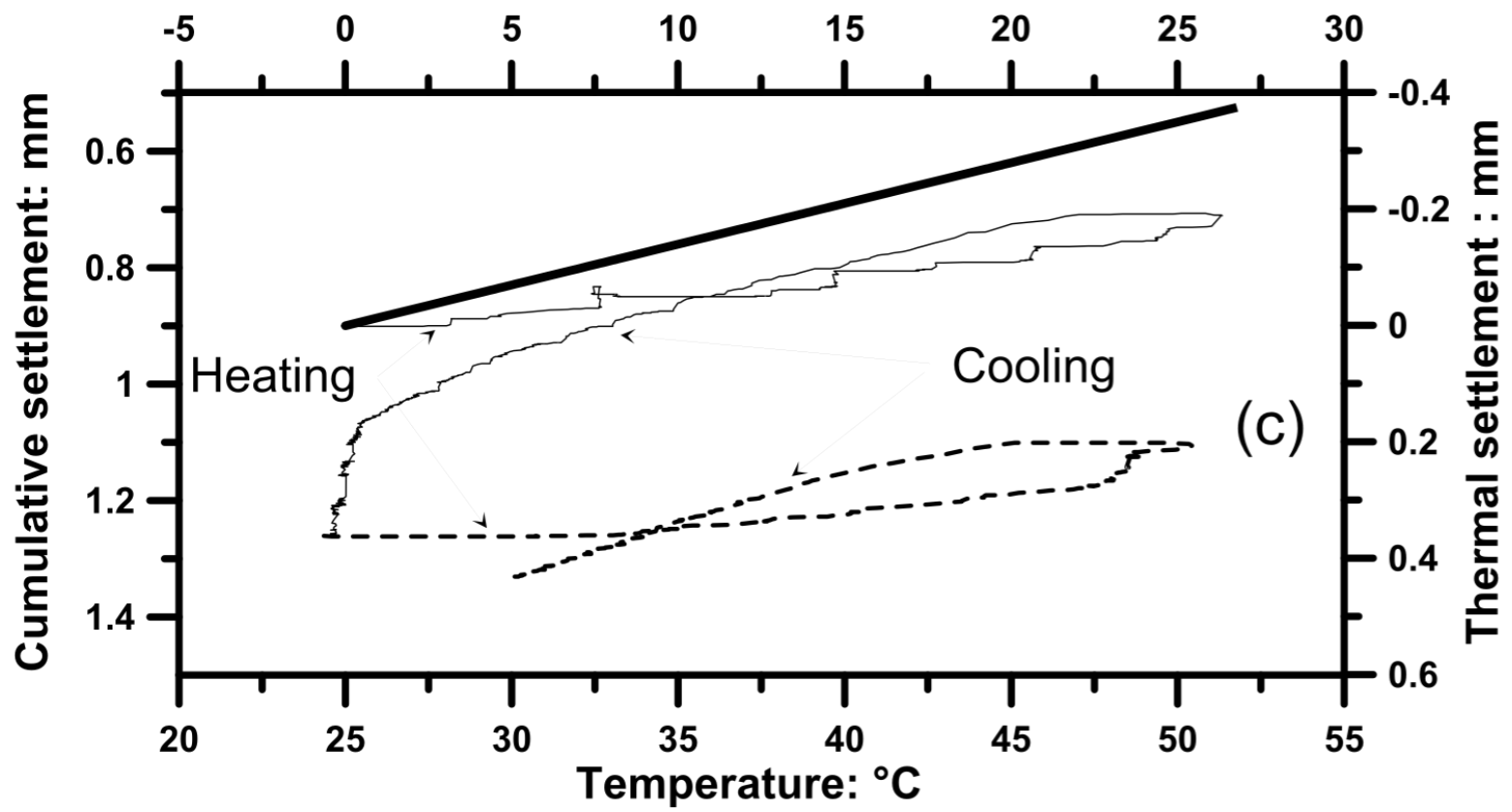

Fig. 6. Experimental results of Test 4. Temperature and pile head settlement during thermal cycles under a pile head load of $500 \mathrm{~N}$. 